\title{
The Secondary Metabolites Composition of Extracts Genista Quadriflora of Morocco
}

\author{
L.Aicha Lrhorfi \\ Fatima Zahra Dahmani \\ Ouafaa Elyahyoui \\ Assia Berrani \\ Amal Samama \\ Saloua Kerrouri \\ Rachid Bengueddour
}

Laboratory of Biochemistry, Biotechnology, Environment and Health. University IBN TOFAIL. Faculty of Sciences. Kenitra, Morocco.

\section{doi: 10.19044/esj.2016.v12n30p79 URL:http://dx.doi.org/10.19044/esj.2016.v12n30p79}

\begin{abstract}
The strategy adopted by our research team aims at the valorisation of some plants for their importance in the economy Moroccan and their uncertain use. Genista quadriflora (G.Q.), one of those plants that has not been investigated before, is a species of the Fabaceae family of widely used in traditional medicine for its therapeutic properties essentially attributable to natural bioactive compounds. In the present work, in order to optimize the future use of G.Q., extracts were prepared from this plant: one aqueous and the other using organic solvents of increasing polarity: petroleum ether, chloroform, ethyl acetate, and methanol. The yields of dry raw organic extracts are of the order of $0.12 \%, 2.15 \%, 7.52$ and 18.41 respectively. Preliminary tests and chromatographic analysis (TLC) identify different bioactive molecules. The quantitative determination of total phenols, condensed tannins and flavonoids by the colorimetric method showed that the extracts are rich in these compounds.
\end{abstract}

Keywords: Genista quadriflora, phytochemical screening, CCM, polyphenols, flavonoids, tannins

\section{Introduction}

Polyphenols are natural compounds widely distributed in the plant reign, which have been growing interest recognitions to their beneficial health effects [Koechlin R.C., 2006]. The role of natural antioxidants 
attracting more and more interest in the prevention and treatment of cancer, inflammatory and cardiovascular disease [Varban I.D., 2009]; they are also used as additives in food, pharmaceutical and cosmetic [Suhaj M., 2006].

Scientific research has been developed for the extraction, identification and quantification of these compounds from plants [Huang D., 2005; Marc Fr., Davin A., 2004; Sanchez-Moreno, C., 2002].

Studies report that the genus Genista belonging to the Fabaceae family is widely used in traditional medicine. For this, we are interested in the study of the species G.Q., which grows wild in the region of Oulmés.

Our study aims at a quantitative and qualitative valorisation of the plant, by colorimetric methods and chromatographic analysis, and evaluation of the antioxidant activity of the organic and aqueous extracts according to the trapping method of free radical DPPH.

\section{Materials and Methods}

\section{Vegetable material}

The plant material was collected in May 2014 during the period of fluoridation, in the region of Oulmés (northern Morocco), identified by the botanical laboratory, university Ibn Tofail; cleaned, dried at room temperature in a well aired room and then sprayed with a power mill to give fine powders.

\section{Plant material and preparation of crude extracts Extraction with increasing polarity solvents}

$25 \mathrm{~g}$ of plant powder was macerated successively at room temperature for $24 \mathrm{~h}$ in $100 \mathrm{ml}$ of each following solution: petroleum ether, chloroform, ethyl acetate and methanol. The filtrates were then concentrated under vacuum using a rotary evaporator until the following gross: petroleum ether, chloroform, ethyl acetate and methanol, which were used for our analyses.

\section{Aqueous maceration}

In parallel, $25 \mathrm{~g}$ of plant powder was macerated in $100 \mathrm{ml}$ of water for $24 \mathrm{~h}$ at room temperature in the dark. The resulting filtrate was evaporated to dryness.

\section{Phytochemical screening Preliminary Tests}

The classic characterisation of different classes of polyphenols G.Q. was used by color reactions (Godin, 1954; Georgievskii, 1990; Dekker, 2002; Wagner and Bladt, 2007; Chaaib Kouri, 2004; Lagnika, 2005). 
TLC

The support, used in this study is a silica gel plate $(20 \times 20 \mathrm{~cm}, 60 \mathrm{~F}$ 254), developed by different gradients migration solvents. After drying, the chromatograms were found either in the visible or UV/366 nm with or without suitable developers.

\section{Determination of total phenols}

The amount of total phenols in the plant was determined by the colorimetric method of Folin-Ciocalteu (Waterman, 1994; Singleton et al., 1999; Heilerová et al., 2003).

$500 \mu \mathrm{l}$ of extract are mixed with $1000 \mu \mathrm{l}$ of Folin-Ciocalteu reagent to $1: 10$ and $500 \mu \mathrm{l}$ of sodium carbonate, $\mathrm{Na}_{2} \mathrm{CO}_{3}, 7.5 \%(\mathrm{w} / \mathrm{v})$. The mixture was stirred, incubated in the dark at room temperature for two hours and the absorbance is measured at $760 \mathrm{~nm}$ by a UV spectrophotometer. The results were expressed in equivalent mg gallic acid/g dry plant material with reference to the calibration curve of gallic acid.

\section{Determination of flavonoids}

The flavonoid content of the extracts was determined using the colorimetric method described by aluminum trichloride by Carnat Lamaison (1991) and cited by Bahorun (1997).

An amount of $50 \mu \mathrm{l}$ of the extract was mixed with $0.95 \mathrm{ml}$ of methanol. After $1 \mathrm{ml}$ of a solution of $\mathrm{AlCl}_{3} 2 \%$ was added. After $10 \mathrm{~min}$ incubation at room temperature in the dark, absorbance read at $430 \mathrm{~nm}$. The results were expressed in equivalent milligrams of catechin per g dry plant material.

\section{Determination of condensed tannins}

The dosage of the condensed tannins was created by the method of vanillin described by Hagerman (2002).

The reagent was prepared by mixing a solution of vanillin (in methanol) at $1 \%$ and a methanolic solution of $\mathrm{HCl} 8 \%$ equally. Standard is used catechin to $0.3 \mathrm{mg} / \mathrm{ml}$. A range of six concentrations of catechin from 0 to $0.3 \mathrm{mg} / \mathrm{ml}$ was prepared from the stock solution. All tubes were then introduced in a water bath at $30^{\circ} \mathrm{C}$ for $20 \mathrm{~min}$. Reading the absorbance at 500 $\mathrm{nm}$ was carried out at the interval of a minute.

The values obtained were used to derive concentrations of extracts condensed tannins from the calibration curve. 


\section{Results and Discussion \\ Extraction efficiency}

Solvents of increasing polarity carried out the successive maceration: petroleum ether, chloroform, ethyl acetate and methanol. The extraction yield obtained for Genista quadriflora (Table 1) was calculated using the following formula:

R (\%) = M. extract/M. Sample * 100 (H.Falleh et al. 2008)

M. extract is the mass of the extract after solvent evaporation in $\mathrm{mg}$;

$\mathrm{M}$. sample is the dry mass of the plant sample in mg.

Table 1: Extraction efficiency of Genista quadriflora

\begin{tabular}{|c|c|}
\hline Solvents & Efficiency (\%) \\
\hline Petroleum ether & 0.12 \\
\hline Chloroform & 2.15 \\
\hline Ethyl acetate & 7.52 \\
\hline Methanol & 18,41 \\
\hline
\end{tabular}

The comparative performance results show that the methanol is a better extraction solvent for Genista quadriflora $18.41 \%$, compared to other solvents (Table 1). And that the solubility of phenolic compounds increases with solvent polarity growth; a reduced amount of polarity (petroleum ether, chloroform, ..) are used to remove the nonpolar compounds (fatty acid, oils, sterols, ...) and the more polar as methanol is used for highly polar compounds as phenolic acids. What justifies the significantly higher efficiency of methanol extraction.

To the aqueous extract, the extraction percentage was not determined because of the difficulty of having a total evaporation.

\section{Phytochemical screening}

The phytochemical screening performed on the extracts intermediary of color reactions or by TLC, gave the results reported in Table 2. TLC visualized under UV at $366 \mathrm{~nm}$ presents spots of different colors, which may correspond to several classes of secondary metabolites. To state the nature of specific flavonoids reagents (reagents Neu), tannins (ferric chloride), the anthraquinons $(\mathrm{KOH})$ coumarins (NH3), alkaloids (Dragendorff) and saponins (sulfuric acid) were used. 
Table 2: Screening phytochemical extracts G.Q. by coloring reactions and by TLC

\begin{tabular}{|c|c|c|c|c|c|c|}
\hline $\begin{array}{c}\text { Class of } \\
\text { compounds }\end{array}$ & $\begin{array}{l}\text { Coloring } \\
\text { reactions }\end{array}$ & Syst.Migration & Without & Revealing & $\begin{array}{l}\text { Spots } \\
\text { major }\end{array}$ & $\mathrm{Rf}$ \\
\hline Flavonoïds & +++++ & $\begin{array}{l}\text { Ethyl acetate/ } \\
\text { Methanol/ } \mathrm{H}_{2} \mathrm{O}\end{array}$ & Yellow & $\begin{array}{l}\text { Neu } \\
\text { Reagent }\end{array}$ & $\begin{array}{l}\text { Yellow- } \\
\text { orange } \\
\text { Pink } \\
\text { Blue- } \\
\text { violet } \\
\text { Cherry- } \\
\text { red }\end{array}$ & $\begin{array}{l}0.65 \\
0.62 \\
0.60 \\
0.42\end{array}$ \\
\hline Anthocyanins & +++ & & & & $\begin{array}{l}\text { Blue- } \\
\text { green } \\
\text { Red to } \\
\text { purple }\end{array}$ & $\begin{array}{l}0.46 \\
0,73\end{array}$ \\
\hline Leucoanthocyanins & +++ & & & & $\begin{array}{l}\text { Red } \\
\text { Red }\end{array}$ & $\begin{array}{l}0,94 \\
0,96 \\
\end{array}$ \\
\hline Tannins & +++++ & $\begin{array}{l}\text { Ethyl acetate / } \\
\text { Methanol/ } \mathrm{H}_{2} \mathrm{O}\end{array}$ & & $\begin{array}{c}\text { Ferric } \\
\text { chloride / } \\
\text { acetic acid / } \\
\mathrm{H}_{2} \mathrm{O}\end{array}$ & $\begin{array}{l}\text { Yellow- } \\
\text { violet }\end{array}$ & $\begin{array}{l}0,11 \\
0,19 \\
0,65 \\
0,73 \\
0,89 \\
0,97\end{array}$ \\
\hline Free anthraquinons & ------ & & & & & \\
\hline $\begin{array}{c}\text { Combined } \\
\text { Anthraquinons }\end{array}$ & & \multirow{4}{*}{$\begin{array}{l}\text { Ethyl acetate / } \\
\text { Methanol/ } \mathrm{H}_{2} \mathrm{O}\end{array}$} & \multirow{4}{*}{-} & \multirow{4}{*}{$\mathrm{KOH}$} & & \\
\hline $\begin{array}{c}\stackrel{{ }_{\nu}}{>} \mathrm{CAO} O- \\
\text { heterosides }\end{array}$ & + & & & & nd & nd \\
\hline $\begin{array}{l}{ }_{y}>\text { - heterosides } \\
\text { reduced genin }\end{array}$ & +++ & & & & - & - \\
\hline$\stackrel{M}{\Delta}$-heterosides & +++ & & & & - & - \\
\hline Coumarins & +++ & $\begin{array}{l}\text { Toluene / Ethyl } \\
\text { acetate }\end{array}$ & Yellow & $\mathrm{NH}_{3}$ & Yellow & 0.62 \\
\hline Alkaloids & +++ & $\begin{array}{l}\text { Ethyl acetate / } \\
\text { Methanol/ } \\
\mathrm{NH}_{4} \mathrm{OH}\end{array}$ & & Dragendorff & Orange & 0.46 \\
\hline Carotenoids & +++ & $\begin{array}{c}\text { Petroleum } \\
\text { ether/Acetone/ } \\
\mathrm{H}_{2} \mathrm{O}\end{array}$ & Yellow & - & - & 0.89 \\
\hline Saponosids & ++ & $\begin{array}{l}\text { Ethyl acetate / } \\
\text { Methanol/ } \mathrm{H}_{2} \mathrm{O}\end{array}$ & & $\begin{array}{l}\text { Vanillin } \\
\text { sulfuric }\end{array}$ & $\begin{array}{l}\text { Pink- } \\
\text { Violet } \\
\text { Yellow- } \\
\text { orange }\end{array}$ & $\begin{array}{l}0.15 \\
0.40\end{array}$ \\
\hline Terpenoids & ++ & $\begin{array}{l}\text { Ethyl acetate / } \\
\text { Methanol/ } \mathrm{H}_{2} \mathrm{O}\end{array}$ & & $\begin{array}{l}\text { Vanillin } \\
\text { sulfuric }\end{array}$ & $\begin{array}{l}\text { Blue- } \\
\text { violet }\end{array}$ & 0.92 \\
\hline
\end{tabular}


Flavonoids exist in yellow in the visible or UV, but Neu reagent reveals in orange yellow, pink, blue violet and cherry red with Rf varies between 0.42 and 0.65 which is consistent with the results of Wagner and Bladt (2007) and spots that have acquired all the blue hues are anthocyanins with Rf between 0.46 and 0.73 .

Tannins are found in purple yellow after spraying with ferric chloride with $\mathrm{Rf}$ between 0.11 and 0.97 . After treatment with $\mathrm{NH}_{3}$ persistence of the yellow spot (Rf 0.62) indicates the presence of coumarins based daphnetin (Dohou et al., 2003).

The appearance of fluorescence yellow, green, blue, orange and after spraying with $\mathrm{KOH}$

visualisation under $\mathrm{UV}$ at $366 \mathrm{~nm}$ indicated the presence of combined anthraquinones. The Dragendorff reagent showed on TLC orange colored spots thus confirming the presence of alkaloids in plant.

In all the results, we have obtained and in accordance with bibliographic data, we uphold the rich extracts secondary metabolites (Table 2), which prompted us to evaluate the antioxidant activity on TLC with DPPH (Cuendet et al. 1997; Mensah, 2004). The results (not yet published) confirm that the extracts have the ability to trap the DPPH. This property was evaluated by the DPPH discoloration technique proves that the plant has an antioxidant potential.

The presence of phenolic compounds (flavonoids, coumarins), alkaloids and terpenoids are probably at the origin of this oxidative activity of the Moroccan species. Flavonoids, recognized as excellent antioxidants (Bruneton, 1999), could play an important role in the defense system. These metabolites are also known for other diverse biological properties (Drissa et al., 2004).

\section{Proportion of total phenols}

The results show that the variation of the total phenols content versus time comparing two extracts is more or less significant; for the aqueous extract ranges from 0.325 to $0.36 \mathrm{mg} / \mathrm{ml}$ and that of the methanol extract between 0.30 to $0.325 \mathrm{mg} / \mathrm{ml}$. 


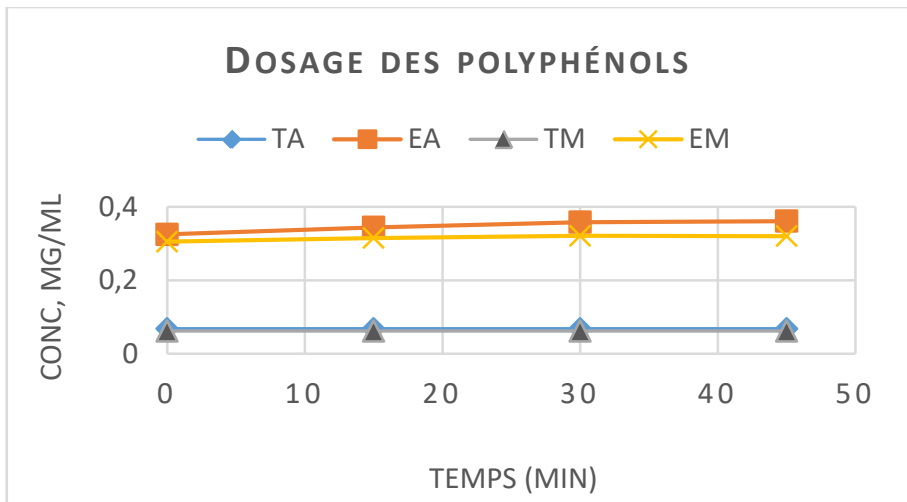

Figure 1: Proportion of total phenols in Genista quadriflora

TA: Aqueous Testifies; EA: Aqueous extract; TM: methanol Testifies; EM: Methanol extract

The quantitative determination of total phenolic extracts revealed that they contain a significant content of these compounds relative to the two blank samples and the optimum time for too extract is 30 min (Fig. 1).

\section{Flavonoids Dosage}

Flavonoids content determined by the method to aluminum trichloride for each extract was reported as $\mathrm{mg}$ of catechin equivalent/g of the dry plant material. The results show that both extracts have moderate levels (Table 3). Based on these data, we can deduce that flavonoids represent $7.69 \%$ of total phenols in the methanol extract. This rate does not exceed $1.53 \%$ in the aqueous extract.

\section{Determination of condensed tannins}

The dosage of the condensed tannins was produced by the method of vanillin described by Hagerman (2002) and the analysis was execute by spectrophotometry at a wavelength of $500 \mathrm{~nm}$. The analysis of the condensed tannin contents shown in Table 3, reveals that the maceration of methanol leads to more effective results, $46.15 \%$ of total phenols, as that performed with the water represent $8.31 \%$. The extraction of condensed tannins depends on their chemical nature, the solvent used and the operating conditions (Chanvan et al. 2001).

Table 3: Levels of total phenols, flavonoids and condensed tannins extracts $G Q$.

\begin{tabular}{|c|c|c|c|}
\hline Extracts & $\begin{array}{c}\text { Total phenols content in } \\
\text { mg GAE/100g of dry } \\
\text { plant material }\end{array}$ & $\begin{array}{c}\text { Flavonoid content in mg } \\
\text { QE/100 g of dry plant } \\
\text { material }\end{array}$ & $\begin{array}{c}\text { Tannin content in } \\
\text { mg CE/100 g of dry } \\
\text { plant material }\end{array}$ \\
\hline Aqueous & 325 & 5 & 27 \\
\hline Methanolic & 325 & 25 & 150 \\
\hline
\end{tabular}


The quantities of total phenols, flavonoids and condensed tannins corresponding to the two extracts examined is reported in mg gallic acid equivalent respectively, catechin and quercetin /100 g dry plant material.

The extraction of polyphenolic compounds is a crucial step for the recovery of these active principles; it depends on the method and suitable solvent that maintain their biological properties. This study shows that, the methanol and aqueous maceration are the best techniques for extracting total polyphenols and condensed tannins, whereas flavonoids is better to try with other solvents.

\section{Conclusion}

In this study, the quantitative determination of phenolic compounds and the antioxidant properties of Genista quadriflora were evaluated. The results obtained may suggest that methanolic extract possess compounds with antioxidant properties, which can be used as natural preservative. These activities were correlated with high level of total phenolic content, flavonoids and condensed tannins. Phytochemical analysis showed that the major chemical constituents of the extract were flavonoids, tannins, alkaloids and saponins. Likewise, these compounds may have potential use as antioxidative preservatives in emulsion-type systems because they are able to scavenge free radicals in a complex heterogeneous medium.

The results of this study also indicate that the by-products, usually disposable, contain significant amounts of polyphenolic compounds that can be exploited at many scales (pharmaceutical, food, cosmetics ...).

\section{References:}

1. Bahorun T., (1997). Substances Naturelles Actives: La Flore Mauricienne, Une Source d'approvisionnement potentielle. Food Agric. Res. N Special: 83-95

2. Bruneton J., (1999). Pharmacognosie, Phytochimie-Plantes médicinales - 3ème Ed Techniques et documentations. Paris. pp: 227-310-312-313-314.494.

3. Chavan U.D., Shahidi F., Naczk M., (2001). Extraction of condensed tannins from beach pea (Lathyrus maritimus L.) as affected by different solvents. J. Food Chem 75, 509-512.

4. Chaaib Kouri, F., (2004). Investigation phytochimique d'une brosse à dents Africaine "Zanthoxylum zanthoxyloides" Thèse de doctorat : Université de Lausanne.

5. Cuendet M., Hostettmann K., Potterat O., (1997). Iridoid glucosides with free radical scavenging properties from Fagraea blumei. Helvetica Chimica Acta, 80, 1144-1152. 
6. Dekker M., (2002). Coumarins: analysis by TLC. Encyclopedia of chromatography, pp. 1-3

7. Dohou N., Yamni K., Tahrouch S., Idrissi Hassani L.M., Badoc A., Gmira N., (2003). Screening

8. Phytochimique d'une ndémique Ibéro-Marocaine, Thymelaea Lythroides Bull. Soc. Pharm. Bordeaux 142, 61-78

9. Falleh H., Ksouri R., Chaieb K., Karray-Bouraoui N., Trabelsi N., Boulaaba M., Abdelly C., (2008). Phenolic composition of Cynara cardunculus L. organs, and their biological activities. C. R. Biology's 331, 372-379

10. Hagerman A.E., (2002). Tannin Handbook. Two Editions. Miami University. Oxford, USA, 116 p.

11. Heilerová L., Bućkova M., Tarapćik P., Silhár S., Labuda J., (2003). Origanum vulgare and Melissa officinalis showed highest antioxidant activity. Czech Journal Food Science 21 (2): 78- 84.

12. Huang D., Ou B., Prior R.L., (2005). The Chemistry behind antioxidant capacity assays. Journal of Agricultural and Food Chemistry 53, 1841-1856.

13. Godin P., (1954). Etude du processus de transformation des acides diet tricarboxyliques chez Penicillium Brevi-compactum Journal Antonie van Leeuwenhoek Volume 21, Issue 1, pp 177-185

14. Georgievskii V.P., Komissarenko N.F., Dmitrouk S.E., (1990). Substances bioactives des plantes médicinales, édition « Naouka » Novosibirsk: 336 p

15. Koechlin-Ramonatxo C., (2006). Oxygen, oxidative stress and antioxidant supplementation, or another way for nutrition in respiratory diseases. Nutrition Clinique et Métabolique 20, 165-177.

16. Lagnika L., (2005). Etude phytochimique et activité biologique de substances naturelles isolées de plantes béninoises. Thèse Soutenue à la Faculté de Pharmacie de Strasbourg

17. Lamaison J.L., Carnat A., (1991). Teneurs en principaux flavonoïdes des fleurs et des feuilles de Crataegus Monogyna Jacq. et de Crataegus Laevigata DC. En fonction de la Végétation. Plant Med Phytother XXV : P 12-16

18. Marc Fr., Davin A., Deglène-Benbrahim L., Ferrand C., (2004). Méthodes d'évaluation du potentiel antioxydant dans les aliments. Erudit, M/S: Médecine Sciences 20(4), 458-463

19. Mensah A.Y., Houghton P.J., Akyirem G.N. A., Fleischer T.C., K.Mensah M.L., Sarpong K., Adosraku R., (2004). Evaluation of the antioxidant and free radical scavenging Pharmacology Journal DOI: 10.1002/Ptr.1614 
20. Sanchez-Moreno C., Larrauri J.A., Saura-Calixto F., (1998). A procedure to measure the antiradical efficiency of polyphenols. Journal Science Technology International, 8, 121-137

21. Sanchez-Moreno C., (2002). Methods used to evaluate the free radical scavenging activity in foods and biological systems. Food Science and Technology International. 8(3), 121-137.

22. Singleton V.L., Orthofer, R., Lamuela-Raventos, R.M. (1999). Analysis of total phenols and other oxidation substrates and antioxidants by means of Folin-Ciocalteu reagent. Methods Enzymol. 299, 152-178.

23. Suhaj, M., (2006). Spice antioxidants isolation and their antiradical activity: A Review. Journal of Food Composition and Analysis 19, 531-537.

24. Vârban D.I., Duda M., Vârban R., Muntean S., (2009). Research concerning the organic technology for Satureja Hortensis L. Culture.Bulletin UASVM Agriculture. 66(2), 225- 229.

25. Wagner H., Bladt S., Zgainski E.M., (2007). Plant drug analysis - A Thin Layer Chromatography Atlas. XIII Springer Verlag. ISBN: 3540-13195-7

26. Waterman P.G, Mole S., (1994) Analysis of phenolic plant metabolites. Wiley, ISBN 0632029692, 9780632029693, 248 pages 